\title{
Implementation of Academic Supervision of Junior High School Supervisors in Indonesia
}

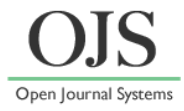

\author{
Akmaludin*, Rohiat, Rambat Nur Sasongko, Aliman \\ Faculty of Teachers Training and Education, University of Bengkulu \\ *Email: akmaludin4691@gmail.com
}

DOI: https://doi.org/10.33369/pendipa.4.2.45-50

\begin{abstract}
The aim of this study was to describe: the planning of academic supervision, the implementation of academic supervision, and the follow-up of academic supervision. The significance of the study was expected to improve the competence of teachers, headmaster and supervisors to achieve qualified educational goals. The research method applied was qualitative descriptive analyzed by terminology of individual and group responses. The data collection was done through the technique of observation, interview, and documentation. The results of the study showed that: (1) the plan of academic supervision to indicate majority of teacheras had not been able to create all the books (first until fourth book), (2) the implementation of class supervision had not been able to be conducted well, and the last (3) the follow-up of supervision was submission of supervision results in the form of comments for improvement, reinforcement, and suggestions. Based on the findings the study, the researchers concluded that the implementation academic supervision of Junior High School supervisors needed to be improved. Teachers, headmaster and supervisors, must have strong partnership to improve the quality of education.
\end{abstract}

Keywords: Academic supervision, junior High School supervisors, Bengkulu city.

\section{INTRODUCTION}

In an effort to improve the teaching process skills and to assess teachers professionally to improve the quality of education that has the characteristics of creative, collaborative, critical, communicative and innovative, a comprehensive supervision should be conducted continuously in the area of National Education Department. The duty bearers at school are supervisors, headmaster to teachers it is in accordance with Regulation of Minister of National Education No. 12 of 2007 on Standards for School/Madrasah Supervisors, which states that supervisor evaluation competency includes assessing the performance of headmaster, teachers and school staff in carrying out the primary duties and responsibilities to improve the quality of education of each subject in the same group, relevant, and the same type.

Regulation of Minister of National Education s No. 16/2017 explains that this teacher competency standards developed entirely from four key competencies, namely pedagogical, professional, personal, and social. These four competencies are integrated in teacher performance as the main task in learning. In Law of Republic of Indonesia No. 14/2005 on teachers and lecturers, there are seven main tasks of teachers and lecturers. The seven tasks are educating, teaching, guiding, directing, training, assessing, and evaluating the learners. Therefore, teachers and lecturers should be able to develop themselves according to the competence and the main task in following the progress of science and technology.

J. Thomas Sergiovany (1983) wrote that Supervisors work primarily in the area of instructional improvement. Organizational demands require most personal in schools to be involved in some aspects of administrative behavior, but for those who work in the area of instructional improvement, supervisory behavior 
will tend to predominate. Sergiovany explains that the supervisors are important in an organization to work in quality improvement, a teaching organization at schools can involve supervisors in some administrative aspects that can improve the institutional quality to help the headmaster, teachers and administrative personnel in their duties, based on their knowledge and ability to provide more services. Supervision can also be performed by the headmaster as a supervisor, but the system of modern education organization stated that it is needed special supervisors that are more independent, and can improve the objectivity of teacher development in carrying out their daily tasks.

Sahertian (2008) asserts that educational supervision none other is the work done to provide services to educational stakeholders, especially to the teachers individually and in groups in an effort to better the education quality, learning process and results. Suharsaputra, (2018) shows that the function of supervision is the activities within the context of role implementation interaction system by a unit or individual to perform its functions to help to improve the quality of education in schools through the relevant activities. Relationship with humanity, fostering the process of group/individual in the administration, evaluation that is done intensively.

Pidarta, (2009) explains that the present supervision make use of things that are measurable, exact if it can be measured objectively, if not then it does not need to be forced. This is consistent with the approach of humanism in education. Therefore, the present supervision applies humanism approaches besides the exact approach within certain limits. This approach is very attentive to the teacher who is being supervised. Mulyadi (2018) expresses that the purpose of academic supervision is to develop the teaching and learning situation into a better direction to increase the growth of students, as well as to prepare for the development of society.

The focus of this study was the Implementation of Academic Supervision of Junior High School Supervisors in Bengkulu City. The problems were stated as follows: (1)
How was the planning of the academic supervision done by Junior High School supervisors at the Junior High School in Bengkulu City? (2) How was the implementation of the academic supervision conducted by Junior High School supervisors in Bengkulu City? (3) How was the follow-up of the academic supervision performed by Junior High School supervisors in Bengkulu City?

The purpose of the study was to describe: (1) the planning of academic supervision conducted by junior high school supervisor in Bengkulu City, (2) the implementation of academic supervision conducted by junior high school supervisor in Bengkulu City, and (3) the followup of academic supervision conducted by junior high school supervisor in Bengkulu City. The benefits of this study are expected to: (a) be used as a reference in the development of research related to the supervision of education for supervisors, researchers and students, (b) be used as guidelines to improve the competence of teachers, headmasters, supervisors and students, (c) be taken into consideration in the promotion of headmasters, teachers and education personnel rotation in order to ensure the management of qualified education.

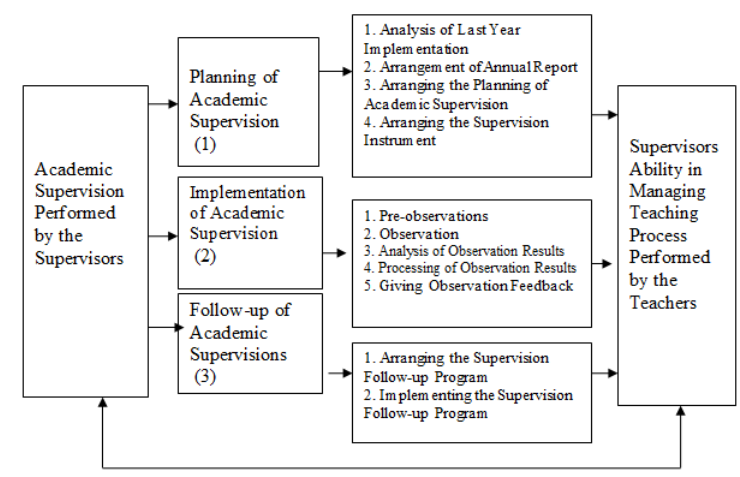

Figure 1. Implementation of Academic Supervision

\section{RESEARCH METHODS}

The research applied qualitative descriptive method which aimed to present a real situation of the implementation of the academic supervision performed by Junior High School supervisors in Bengkulu City. The research was conducted for one year from 2018-2019. The subject of study are teachers, headmasters and academic 
supervisors. Data collection techniques used were: (a) observation, (b) interviews, and (c) documentation. Qualitative research intends to confer meaning on phenomena holistically and portray themselves actively in the whole process of research to find the essential truth scientifically and logically, in the development of knowledge and theory after determining the problems and data in the field. Data will be analyzed based on the meaning that is qualitative analysis and explaining the facts.

Bungin, (2007) describes the study design was Grounded Research namely, phase 1/ preliminary observation, phase $2 /$ data collection, and stage 3/ advanced data collection. Data on qualitative research are in the form of words and are analyzed by phenomenologism approach that is to break down a human subject which is generally inconsistent/ changeable and so on. Thus, a qualitative analysis approach uses inductive logic approach, the approach uses thinking logic of seated pyramid syllogism.

\section{RESULTS AND DISCUSSION}

There were 25 Public Junior High Schools, 28 Private Junior High Schools in Bengkulu City, thus the total number of Junior High School in Bengkulu City was 53 schools. The total numbers of classes were 568 and the students were amounted to 14,122 people, the number of certified and non-certified teachers were 3,239. This data was obtained from the result of researchers work visit with the supervisors to schools through monthly reports delivered to the supervisors.

Supervisors conduct coaching mentoring, monitoring, and assessment of the performance of teachers about lesson planning, learning implementation, and follow-up of learning as a result of the evaluation of supervision to improve the quality of teachers and education personnel in achieving the goal of education, therefore the academic supervisors need to pay attention to things of their focus fields at school. Implementation of academic supervision in the school can be seen in the diagram scope of academic supervision below (MONE, 2011).

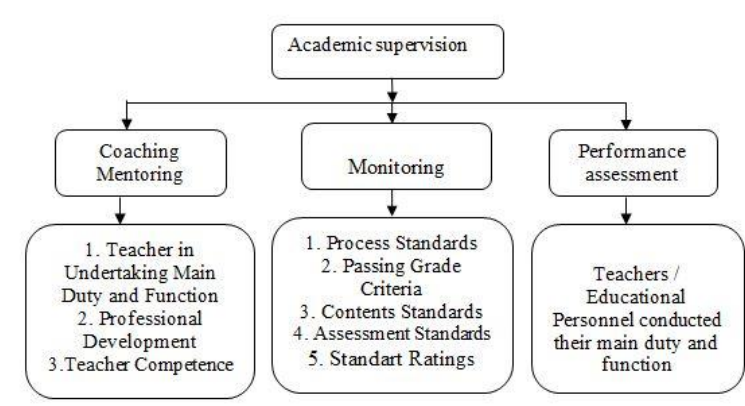

Figure 2 Diagram of Academic

\section{Supervision}

\section{Supervision Planning Activity}

The supervisors analyze the implementation of supervision of the previous year to make an assessment of supervision for the following year, compiling the semester program and the annual program, arranging the academic supervision program that will be carried out, and developing instruments of supervision based on planning activities that have been analyzed as a priority in the implementation of the supervision to be carried out. Teachers make the administration of learning in book 1, 2, 3, and 4 completely and will verified in advance by the supervisor concerning about the validity before carrying out supervision, the next step is planning the classroom supervision implementation by preparing the specific lesson plan according to the on-going materials based on Core Competence and Basic Competence that will be used, starting from the schedule of the implementation, selection of the materials, method, media, instrument, approach, student worksheet, test specification and test item as well as assessment sheet that will be used at the time of implementation of supervision.

\section{Implementation Supervision Activity}

In the implementation of the supervision, the supervisors create an intimate atmosphere with teachers from pre-observation, observation implementation, planning and implementation process of teaching and learning, carry out the analysis of the results of observations, manage 
the observation results and perform feedback on the observation results. Supervisors act as partners of teachers and headmasters to increase the quality of education and follow-up. Supervisor position themselves as partner and not as inspector to point out mistakes made by teachers in the classroom, instead they apply the principles of academic supervision, according to (PPTK, 2014) namely practical, systematic, objective, realistic, anticipatory, constructive, cooperative, intimate, democratic, active, humanistic, sustainable, integrated, and comprehensive for curriculum development and professional development.

Academic supervision can be done on some of the teachers who complete the learning tools and several teachers with minimal administrative, because most teachers have not been able to own learning tools of books $1,2,3$, and 4, thus the expected competencies achievement only at level $\mathrm{C} 1$ about knowledge, some teachers reached the C2 about differences, while at C3 level about criticism, creative, collaborative and communicative corresponding with Bloom Taxonomy had not yet seem to be achieved. In this today era of industry and technology, we are faced with learning on the civilization of 4.0 and $21^{\text {st }}$ century learning that our students should master lesson on the level of Higher Order Thinking Skills (HOTS) or understanding about the high level questions as expected by the ministry of education in K 13 , the implementation of teaching method should be scientific and varied as well as be able to motivate students to be critical, creative, collaborative and communicative and enjoyable.

Teachers in teaching should be rich in methods and varied to avoid monotony in teaching, to motivate students to study harder, learn to use technology, use the learning media, use other teaching aids that are relevant to teach students to be able to open up the minds and provoke students to be active, creative, collaborative and communicative according to their talents and interests, and motivate learning. Hidayat (2017) explains that learning which had been being conducted all of this time was resultsoriented / mastering the material must be changed into learning as a process (changing the paradigm), therefore the learning should as much as possible engage learners through scientific approach for the learners are able to explore to master certain competencies.

In making the learning tools, teachers generally just copy and paste what is in the internet, without firstly editing and analyzing the lesson accordance with Passing Grade Criteria, Core Competence, and Basic Competence, syllabus and formulation of the GPA, learning materials, learning model, assessment of attitudes, knowledge and skills, objectives, indicators, allocation of time based on academic calendars, effective weeks, and distribute them into the Lesson Plan, semester program / annual program. It is caused by the many teachers who are still face difficulty in their preparation. Teachers should be able to write their own learning instrument or through $M G M P$ to finish books 1,2,3, and 4, before coming back to school after the holidays of the semester report reception.

Supervisory has very important function in schools to help teachers to improve pedagogical, professional, and social personalities to deal with the student in the learning process. Glickman, in Ministry of Education and Culture, through Ministry of Education and Culture GTK, (2018) explains the academic supervision as a series of activities to help teachers develop the ability to manage the learning process for the achievement of learning objectives. Thus, the essence of the academic supervision was not evaluating the performance of teachers in managing the learning process much less killing the teacher career, instead it assists and motivates teachers to develop themselves and their abilities professionally in planning, implementation and follow-up of the learning.

\section{Follow-up Activities}

Supervisors analyze the results of the supervision and discuss the appearance and the use of instruments tailored to the treatment in classes held during classroom supervision. Coaching activities are in the form of direct and indirect guidance. Direct coaching is done on particular matters which need to undergo repair immediately from the analysis results of the newly done supervision. Indirect coaching is done on matters of a general nature that need repair and attention after obtaining the results of 
the analysis of supervision in a wide range of issues related to education quality improvement expected by the public.

Supervisors has not figured fullest cooperation in the implementation of academic supervision at school in accordance with the Regulation of Ministry of Education and Culture No. 15 of 2018, that the supervisor duty is for 40 hours and was reduced by 2.5 hours per week for rest, which means to 37.5 hours is for office and school as well as to complete the report. It can be seen from the presence of inspectors to the school in coaching mentoring, monitoring and performance assessment in target schools in the managerial and academic partner schools through a special guest book coaching in schools. The presence of supervisors in managerial target schools is in a higher frequency while the presence in the academic partner schools is very low. Haris (2018) describes The role of the supervisor is a critical role for MoEC as it delivers a number of system and school priorities to improve student outcomes. Unfortunately, the assignment of school supervisors has often been inadequately resourced to carry out this role, in conflict with other countries where the most needy schools are given the most significant professional support to improve outcomes.

From the quote above, it can be seen how important the monitoring in managing education is, but the policies done are more dominant than the regulations that should be adhered to by local government resulting in the meaningless of the Ministry Regulation, Law and Government Regulation that have been published / enacted and impact on quality of education expected by society was not yet realized well, with a number of systems and priorities for the development of education that should be implemented are to be ignored. Supervisors cannot do very much by regulation to be implemented properly due to cooperation of supervisors, headmasters and teachers have not been able to be realized well.

Organizing school supervision should be based on the organized needs and more to a visit that had been scheduled, capacity development for headmasters, supervisors and teachers and education personnel in order to boost the quality of teachers, students, and educators to improve the competence, for example: (a) workshop of arranging the learning tools books 1, 2, 3, and 4, (b) the activities of professions that are sustainable, (c) a program of qualified counseling guidance (d) writing of book and action research required by the teacher, as well as other activities that are beneficial for teacher promotion and student activities such as training of scientific writings, coaching/training in the studies of science, social, art, religion and exercise that can boost student achievement according to their talents and interests.

In the Regulation of Minister of State for Administrative Reform and Bureaucratic Reform No. 21 Year 2010 Chapter 1 Verse 2: The school supervisors are the civil servants who take full responsibility and authority for supervising academic and managerial at education unit. Because they are in school with fully responsibility for the oversight and outcomes of educational supervision that they do, and they should be used as a reference for decision-making on policy and the empowerment of civil state apparatus. Teachers, educational personnel, and the headmaster both for promotion, and headmaster and education personnel transfer in the environment of education department according to regulations that have been issued.

In the assessment standards, teachers conduct them based on BSNP which means to have followed the assessment criteria in accordance with the instructions or regulations of the applicable assessment standards and in accordance with the curriculum used at the current time, but in writing report cards generally they ask for help to school operator or certain teachers that can help them to type student report card contents to be filled. In learning mastery each student is expected to exceed the passing grade criteria, if the student has not passed yet then he/she is given remedial, in conducting remedial there were still teachers who were wrong in the technical implementation, remedial was done with repetition or revaluation without prior learning. Actually, the teacher must make a special remedial program and performed it in schools outside the regular class hours after, after that the teacher done the assessment. 


\section{CONCLUSION}

Implementation of academic supervision could be carried out optimally in accordance with the planning and implementation by the supervisor due to the following reasons: (1) Planning supervision: the incompletion of the book 1, 2, 3, and 4 by the teachers, (2) Implementation supervision: the lack of willingness of teachers to be supervised in their classes, the frequency of supervision in schools was still low and the lack of activities that can boost the quality of teachers, administrative personnel education at school, (3) Follow-up activities: The explanation and evaluation of appearance teachers on classroom supervision were shortage and overtage in the next implementation.

\section{REFERENCES}

Bungin, Burhan (Ed.), 2015. Metodologi Penelitian Kualitatif Aktualisi Metodologis Ke Arah Ragam Varian Kontemporer. Jakarta: Rajawali Perss.

Haris, I., Naway, F., Pulukadang, W. T., Takeshita, H., \& Ancho, I. V., 2018. School Supervision Practices in the Indonesian Education System; Perspectives and Challenges. Journal of Social Studies Education Research, 9(2), 366-387.

Hidayat, Sholeh, 2017. Pengembangan Guru Profesional. Bandung: PT Rosda Karya.

J., Thomas sergiovanni and Robert J Starratt, 1983. Supervision Human Perspectives. New York: Mc GrawHill Book Campany.

Kemendikbud Dirjen GTK, 2018, Supervisi Akademik Modul Pendidikan dan Pelatihan Fungsional Calon Pengawas Sekolah dan Penguatan Kompetensi Pengawas Sekolah, Jakarta: Kemendikbud Dirjen GTK.
Mulyadi dan Eva Swastika Fahriana, 2018. Supervisi Akademik, Konsep, Teori, Model Perencanaan, dan Implikasinya. Malang: Madani.

Nur, Rambat Sasongko, dkk, 2014. Pedoman Penulisan Karya Ilmia Program Studi Doktor Ilmu Pendidikan. Bengkulu: FKIP, Indonesia.

Peraturan Menteri Pendidikan Nasional No. 12, 2007. Tentang Standar Kompetensi Pengawas Sekolah/Madrasah. Jakarta: Kemendiknas.

Peraturan Menteri Negara untuk Reformasi Administrasi dan Reformasi Birokrasi No 21 Tahun 2010, Indonesia.

Peraturan Menteri Pendidkan Nasional No. 16, 2017. Tentang Standar Kompetensi Guru. Jakarta: Kemendiknas.

Peraturan Menteri Pendidikan dan Kebudayaan Republik Indonesia No. 15 Tahun 2018. Tentang Pemenuhan Beban Kerja Guru, Kepala Sekolah,dan Pengawas Sekolah. Jakarta: Kemendikbud.

Pidarta, Made, 2009. Supervisi Pendidikan Kontekstual. Jakarta: PT Rineka Cipta.

Pusat Pengembangan Tenaga Kependidikan, 2011. Buku Kerja Pengawas Sekolah. Jakarta: Kementerian Pendidikan Nasional.

Sahertian, Piet A., 2008. Konsep Dasardan Teknik Supervisi Pendidikan. Jakarta: RinekaCipta.

Suharsaputra, Uhar, 2018. Supervisi Pendidikan Pendekatan Sistem Berbasis Kinerja. Bandung: PT Refika Aditama.

Undang-undang No. 14, 2005. Tentang Guru dan Dosen. Jakarta: Kemendiknas.

Pengembangan Tenaga Pendidik dan Kependidikan, PPTK, 2014. Supervisi Akademik Implementasi Kurikulum 2013. Jakarta: BPSDM. 